This item was submitted to Loughborough's Research Repository by the author.

Items in Figshare are protected by copyright, with all rights reserved, unless otherwise indicated.

\title{
Crime and Disorder Act 1998: Section 17. A wolf in sheep's clothing
}

PLEASE CITE THE PUBLISHED VERSION

PUBLISHER

(C) Perpetuity Press

LICENCE

CC BY-NC-ND 4.0

\section{REPOSITORY RECORD}

Moss, Katrina, and Ken Pease. 2019. "Crime and Disorder Act 1998: Section 17. A Wolf in Sheep's Clothing". figshare. https://hdl.handle.net/2134/929. 


\title{
Crime and Disorder Act 1998: Section 17 A Wolf in Sheep's Clothing?
}

\author{
Katrina Moss and Ken Pease ${ }^{1}$
}

In Britain, s 17 of the Crime and Disorder Act 1998, whereby local authorities are enjoined to have due regard to crime and disorder prevention in the exercise of their functions, is regarded as potentially the most important part of that Act. An example is given of how actions of local authorities may be challenged by judicial review, and what the nature of a defence to such challenge might be. Recommendations are made as to what the actions of a prudent local authority should now be in the light of the potentially profound implications of 17.

Key Words: Crime and Disorder Act 1998, s 17; local authorities; crime drivers; Secured by Design (SBD); judicial review

The last decade has seen a major change in the perception of which agencies should properly contribute to the reduction of crime. Hitherto in Britain the police were assigned primary responsibility for that task. More recently, the notion of partnerships in crime reduction has served to stress the significant crime reduction roles of public bodies, notably local authorities. The process which began with the Morgan Report ${ }^{2}$ in 1991 has culminated in the Crime and Disorder Act 1998, which designates local authorities and the police as jointly constituting local 'responsible authorities'.

Section 17 of the Crime and Disorder Act imposes a duty on each local authority to:

exercise its functions with due regard to ... the need to do all that it reasonably can to prevent crime and disorder in its area.

The Home Office Consultation Document 'Getting to Grips with Crime: A New Framework for Local Intervention', ${ }^{3}$ stated that the purpose was to

give the vital work of preventing crime a new focus across a very wide range of local services ... It is a matter of putting crime and disorder considerations at the heart of decision making ...

Section 17 is arguably the most radical part of the Act. This appears not yet to have been recognised, even among government and local authority officials. More than once we have proclaimed the section's importance to such officials, the response being a diffident 'Remind me what that says'. Probably the lack of recognition results from the compartmentalisation of thought which besets discussions of crime and criminality. Specifically, the problem of crime tends popularly to be reduced to the problem of what to do about the criminal. ${ }^{4}$ The provisions of the Act which concern what to do with offenders have thus attracted most comment. Yet the real drivers of 


\section{Crime Prevention and Community Safety: An International Journal}

crime lie in our social and physical arrangements. The layout of our schools dictates how often they are burgled..$^{5}$ The location and surveillability of phone kiosks determine how often they are vandalised. ${ }^{6}$ The layout of petrol stations is a factor in the rate at which motorists drive off without paying. ${ }^{7}$ Crime rates respond to road layout. ${ }^{8}$ More obviously, the rate of domestic burglary is without question influenced by the security we install. ${ }^{9}$ Housing allocation determines crime rates on local authority estates. ${ }^{10}$ Examples here are illustrative only. ${ }^{11}$

Because these 'crime drivers' pervade every sphere of local authority responsibility, it is difficult to conceive of any decision which will remain untouched by s 17 considerations. Do you want to close a road? Crime patterns respond to such closures. Do you want to undertake or permit the building of homes? Unless you ensure that they are built to 'Secured By Design' standards, they will be burgled more. Unless you can ensure rapid repair of council homes which have been burgled, they are liable to be burgled again. Sometimes the prevention of crime is at odds with other duties. ${ }^{12}$ Street lighting can reduce crime. ${ }^{13}$ In areas of mixed housing, limits on the uses to which housing revenue may be put may lead (for example) to a failure to upgrade lighting, with victimisation of both owner-occupiers and council tenants.

There are thus many circumstances in which an individual citizen, a business or a residents' group could plausibly argue that a local authority had breached s 17 . To take one example: someone moves into a new home. For the purpose of the Act it does not matter whether the home is council-owned or a private development. The new resident is burgled repeatedly. She is told by the police that her new home is not built to Secured By Design standards, despite the area's high rate of burglary. A Residents' Association meeting is convened, and she finds that the experience is not unusual: burglars always gaining entry in the same way because of a clear design weakness. With the Association's support, she successfully seeks a judicial review of the authority's actions, with the expectation of a decision of mandamus, whereby the security uprating of the homes to SBD is ordered. Such a process, perhaps multiplied many times in different areas and circumstances, will hopefully clarify authorities' duties under s 17.

Judicial Review provides the means by which the courts control or assess the exercise of government powers, including those delegated to local authorities. In essence (and subject to any changes that might occur in respect of the implementation of the Freedom of Information and Human Rights Acts 1998) the courts seek to ensure three principal objectives:

- that Acts of Parliament have been correctly interpreted;

- $\quad$ that discretion conferred by statute has been lawfully exercised;

- that the decision maker has acted fairly.

It is normally only as a result of judicial decisions that administrative agencies can fully appreciate the scope of their actions, and aggrieved citizens be granted one of the available remedies. Statutes necessarily confer discretion, so in what way should a local authority exercise this discretion under s 17 whilst at the same time avoiding potentially costly legal actions? The courts have been reluctant to set narrow limits to the exercise of wide discretionary powers vested in local authorities. However, if the statute conferring the discretion expressly or impliedly indicates matters to which the authority ought to have regard, it must have regard to them. ${ }^{14}$ The statutory invocation of crime and disorder prevention cannot, therefore, be neglected with safety.

In the case outlined above it might be possible for the local authority to argue that $\mathrm{s} 17$ is not 'intended' to impose an onerous duty upon local authorities but without judicial precedent it is currently impossible to say. Did East Sussex County Council ${ }^{15}$ anticipate the scope of their 
duty under s 41 Highways Act 1980 which provided that they maintain and repair the highway? In this case, a decision by the authority to salt roads no earlier than 5.30 am after a frost forecast the previous night was held to be in breach of their statutory duty under s 41 . The plaintiff in the action had skidded off the road and sustained serious injuries at $7.10 \mathrm{am}, 15$ minutes before the salt lorries arrived at this particular stretch of road. East Sussex County Council was held by the Court of Appeal to have 'failed to act expeditiously to prevent ice forming on the surface of the road and were therefore in breach of their statutory duty to maintain it'.

This is in spite of the fact that the Act provides a defence to such actions (s 58) wherein 'it is a defence ... to prove that the authority had taken such care as in all the circumstances was reasonably required'.

The 'reasonable requirement' defence is implicit in s 17 itself. 'Due regard' can reasonably mean that crime reduction concerns are offset by considerations of cost, for example. However, to persist with our example, SBD building incurs little or no cost on the authority unless no developer can be found to comply with these standards in an area with acute housing needs. In such (improbable) circumstances, the effort to secure SBD standards may well be enough successfully to defend an authority.

What would it be prudent for local authorities to do now? Three precautionary steps are, in the writers' view, necessary:

- To agree which practices are, on the evidence, likely to be criminogenic. This should, at least in the first instance, assume the presence of those with criminal inclination, and should not cover education, social service and other people-processing practices which may (or may not) affect the supply of those with criminal inclination. There is plenty to discuss where s 17 failure may lead to immediate recourse to judicial review, without muddying the waters with (for example) the failure to provide youth services whose effects (if any) will take longer to appear. In short, emphasis should be upon primary crime prevention both because the evidence is clearer there and because it is from failures to implement primary prevention that the early challenges are likely to come. The reason for establishing a repertoire of criminogenic practices is that it provides an agenda, so that the backdrop to judicial review will be the scope of s 17 practices agreed by local authorities, not the failure even to consider their possible scope.

- To effect immediate implementation of criminocclusive practice under the first point, which has zero cost or costs so trivial that they will certainly be offset by direct savings which attend crime reduction (such as the insistence on Secured By Design building).

- To make policy decisions, after legal advice, concerning the trade-off between s 17 obligation and extra expenditure. The most difficult cases will be those (perhaps as in East Sussex) where such a trade-off is necessary. Such a trade-off does involve risks of litigation, but better a reasoned position than policy drift and its aftermath.

Even such a relatively simple (and uncontentious?) programme for action will be challenging for local authorities. As one of the anonymous reviewers of this paper aptly put it: 'An important issue is ... the practical aspects of incorporating crime and disorder considerations into policy decisions. How can or will it be done through existing local government machinery?' We have chosen not to address this important point in this paper. We would like to see it primarily as a wake-up call, with a menu for the policy equivalent of breakfast! The danger would be that by 


\section{Crime Prevention and Community Safety: An International Journal}

developing menus for the whole day, agreement about the need for action would be obscured by disagreement about our elaboration of what such action might consist of. ${ }^{16}$

That said, one issue certain to be raised is whether recourse to law would be undertaken more often by people in areas not chronically victimised. Distributive justice requires that, if $\mathrm{s} 17$ is to be used, it should at least be used by those who have suffered most. Can we rely on a new breed of public interest lawyers to arise and take up the cudgels on behalf of the poorest people in the most deprived areas, or must we make other arrangements?

\section{Notes}

Kate Moss is Senior Lecturer in Law at Staffordshire University, Leek Road, Stoke-on-Trent, ST4 2DF. Ken Pease is Professor of Criminology at Huddersfield University, c/o Holmfirth Police Station, Holmfirth, West Yorkshire, HD7 2TT.

Morgan Report (1991) Safer Communities: The Local Delivery of Crime Prevention through the Partnership Approach. London: Home Office.

Home Office (1997) Getting to Grips with Crime. A New Framework for Local Intervention. London: Home Office.

One of this paper's anonymous reviewers commented, 'I think it is quite wrong to suggest that the problem of crime tends to be reduced to the problem of what to do about the criminal. Local authorities have considerable experience now in design against crime'. We acknowledge recent activity in this respect, although local experience and the expertise on which it is based are both patchy. However we contend that public debate is as we characterise it, and that this is reflected in the over-representation of 'people-processing' departments in local groups taking the implementation of the Act forward, and in the previous careers of community safety officers? Where, for example, is the community safety officer who comes from a Trading Standards background, an area of work at least as relevant to crime control as probation and social services, which yield so many community safety officers? Moreover Sutton ((1996) Implementing Crime Prevention Schemes in a Multi-Agency Setting: Aspects of Process in the Safer Cities Programmes. Home Office Research Study, 160. London: HMSO) discerns a move away from design against crime among relevant practitioners.

5 Hope, T. J. (1980) Four Approaches in the Prevention of Property Crime in Schools. Oxford Review of Education. Vol. 6, pp 231-240; Hope, T. J. (1982) Burglary in Schools: The Prospects for Prevention. Home Office Research and Planning, paper 2. London: Home Office; Hope, T. J. (1986) School Design and Burglary. In K. Heal and G. K. Laycock (eds) Situational Crime Prevention: From Theory into Practice. London: HMSO.

Mayhew, P. M. and Winchester, S. W. C. (1980) Natural Surveillance and Vandalism to Telephone Kiosks. In R. V. Clarke and P. M. Mayhew (eds) Designing Out Crime. London: HMSO.

La Vigne, N. (1994) 'Gasoline Drive-Offs: Designing a Less Convenient Environment'. In R. V. Clarke (ed.) Crime Prevention Studies 2. Monsey, NY: Willow Tree Press.

Beavon, D. J. K., Brantingham, P. L. and Brantingham P. J. (1994) The Influence of Street Networks on the Patterning of Property Offences. In Clarke, op cit; Matthews, R. (1992) Developing More Effective Strategies for Curbing Prostitution. In Clarke, R. V. (ed.) Situational Crime Prevention: Successful Case Studies. Albany, NY: Harrow and Heston.

Budd, T. (1999) Burglary of Domestic Dwellings: Findings from the British Crime Survey. Statistical Bulletin 4/99. London: Home Office.

10 Bottoms, A. E. and Wiles, P. (1991) Housing Markets and Residential Community Crime Careers. In Evans, D. J., Fyfe, N. R. and Herbert, D. J. (eds) Crime, Policing and Place: Essays in Environmental Criminology. London: Routledge. 
11 For many more, see Pease, K. (1997) Crime Prevention. In M. Maguire et al (eds) Oxford Handbook of Criminology, (2nd edn) Oxford: Clarendon.

12 Pease, K. (1998) Repeat Victimisation: Taking Stock. Police Research Series, 90. London: Home Office.

13 Painter, K. (1996) Street Lighting, Crime and Fear of Crime. In T. Bennett (ed.) Preventing Crime and Disorder. Cambridge: Institute of Criminology.

14 Associated Provincial Picture Houses Ltd v Wednesbury Corp. [1948] 1 KB 223 at 228, [1947] 2 All ER 680 at 682.

15 Goodes v East Sussex County Council [1999] The Times, 7 January, CA.

16 Statutes cited are Crime and Disorder Act 1998; Freedom of Information Act 1998; Human Rights Act 1998; Highways Act 1980. 